\title{
脆性破壊の発生に関寸る研究 (第2墽)
}

一鋼板の破壊発生特性について—

$\begin{array}{lll}\text { 正員 } & \text { 原 } & \text { 博* } \\ \text { 正員 池 } \text { 田 一 夫** }\end{array}$

On Brittle Fracture Initiation (Second Report)

-Brittle Fracture Initiation Characteristics-

By Hiroshi Kihara, Member

and Kazuo Ikeda, Member

\section{Summary}

In the first report, one of the authors succeeded in the brittle fracture initiation at low stress levels from the notch without any additional factors such as the welding residual stress, the impact stress and the metallurgical embrittlement etc. by using the deep notch test.

In this paper, firstly, a review of the fundamental theories of fracture initiation and the theoretical extension of the results of deep notch test to the brittle fracture initiation characteristics for an infinite plate were made.

Secondly, the following fundamental experiments on brittle fracture initiation were conducted : (1) Classification of zones for fracture initiation. (2) Applicability of the Griffith-Orowan energy condition. (3) Size of yield zone around the tip of notch. (4) Effect of plate thickness.

Next, the brittle fracture initiation characteristics for various steels such as the mild steel, various high strength steels including HT60, HT70, HT 80, HT100, and various low temperature steels including $2.5 \% \mathrm{Ni}, 3.5 \% \mathrm{Ni}, 9 \% \mathrm{Ni}$ steels and Al-killed steels quenched and tempered with the yield strength of $33,37,58 \mathrm{~kg} / \mathrm{mm}^{2}$ were evaluated.

Lastly, the correlations between the brittle fracture initiation temperature for a crack length of $10 \mathrm{~mm}$ under a stress level of $\sigma_{y} / 2.56$ and the transition temperatures in various large and small size brittle fracture tests were investigated.

1. 序

論

溶接構造物の脆性破壞にたいする安全性を確保するためには, 脆性破壞の発生, 伝播, 停止に関する機構があ きらかにされ，また各種鋼板の脆性破壊特性が正しく評価されることが必要である。

脆性破壞の発生に関する研究は実際には最も重要であるにも拘わらず, 実験室で低応力で脆性破壞を発生させ るのに, 通常, 切欠のほかに種々の要因を附加しなければならなかつたので, これまでその発生機構の研究が困 難視され，他の分野に比しておくれている。

第 1 報に括いて秋田，池田ら ${ }^{1)}$ は深い切欠を有する広巾試験片を低温で引張り，他の要因の附加なしに脆性破 壊を発生させることに成功し，ついで木原，池田 ${ }^{2}$ は軟鋼，高張力鋼执よび低温用鋼について deep notch test を実施して有限巾の試験片の場合の脆性破壞発生特性をしらべた。

本報告では, 有限巾の試験片でもとめられた脆性破壞発生特性を無限板の場合に挔張して評価することのほ か, 破壞の分類, エネルギー条件式の適用, 切欠き先端部の塑性域の大きさ, 板厚効果, 各種鋼板の脆性破壞発

原稿受付 昭和 40 年 7 月 10 日

* 東京大学工学部 船舶工学科

** 船舶技術研究所 船体構造部 
生特性 (無限板の場合), 各種大型, 小型脆性試験の遷移温度との相関性等についてのべる。

\section{2 脆性破壊発生の理論の検討}

㤏性破壞の発生の理論としては微視的，物性論的な見地，および巨視的，工学的な見地から種々検討が括こな われてきた。後者に関しては寺沢, 大谷ら ${ }^{3)}$ の破壊応力曲線の概念もあるが, ここでは主として後者のうちのエ ネルギー論に関連したものについてのべる。

長さ $2 \mathrm{c}$ の亀裂を有する無限板に执いて, 亀裂に直角方向に無限遠に扎いて一様引張応力のが作用して, 亀裂 長さが微小長さだけ伸長した際のエネルギーの平衡をとり㤁から。すなわち, このとき解放される弾性歪エ ネルギーの変化率が，新しい破面を形成するに要する仕事より大きいか等しいと不安定破壞が生ずると考える。 Griffith $^{4)}$ 执よび Orowan ${ }^{5)}$ によるとこの条件式は次式によりあらわされる。

$$
\frac{\pi \sigma^{2} c}{E} \geqq 2 S
$$

ただし， $E=$ ヤング率， $S$ =塑性表面エネルギー

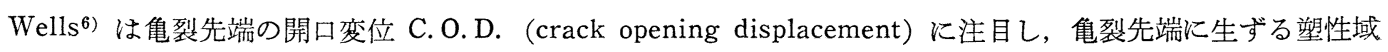
の大きさを考虑して, 破壞が発生するときの開口変位 $\delta$ をらべ, これが温度の上畀とともに増加することをし つた。

general yielding 状態に入る前には $\delta$ は次式であらわされる。

$$
\delta=\frac{4 G}{\pi \sigma_{y}}
$$

すなわち開口变位は crack extension force $G$ に比例し, 降伏点 $y$ に反比例する。この場合の塑性域の大きさ $\left(2 r_{y}\right)$ は次式でもとめられる。

$$
\frac{c}{r_{y}}=2\left(\frac{\sigma_{y}}{\sigma}\right)^{2}-1, \quad \sigma<\sigma_{y}
$$

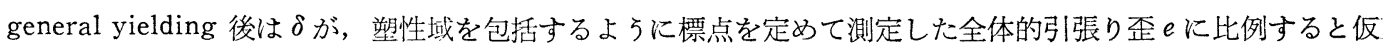
定して開口変位をあとめ次式が得られた。

$$
\delta=2 \pi e c, \quad \sigma>\sigma_{y}
$$

Bilby, Cottrell および Swinden7) は単純な転位模型をもちいて, 無限板に長さ $2 c$ の亀裂がある場合の亀裂 先端の塑性変位について理論計算を抏こなつた。そして破壊の発生は龟裂先端の塑性変位が限界值に達すると生

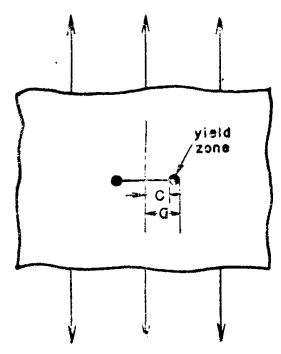

第 1 図亀裂先端部の 望栍域 ずると考えた。この限界值は温度の上界ととるに增加する。

第 1 図に示すように，亀裂長さの $1 / 2$ を，塑性域をらくむものを $a$ とすると両者 の関倸は次式であらわされる。

$$
\frac{c}{a}=\cos \left(\frac{\pi \sigma}{2 \sigma_{y}}\right)
$$

$\sigma<0.6 \sigma_{y}$ の場合には（5）式は近似的に次式であらわされる。

$$
\frac{a}{c}=1+\frac{1}{8} \pi^{2} \frac{\sigma^{2}}{\sigma_{y}^{2}}
$$

この転位論をもとにしてもとめた $\sigma / \sigma_{y}$ にたいする $a / c$ の值を Hult および Mc Clintock が工学的にもとめた弾塑性解と比較すると両者が良く一致していた。

切欠先端に拈ける塑性変位は次式であらわされる。

$$
\Phi(c)=\frac{4 c \sigma_{y}}{\pi E} \ln \left(\frac{a}{c}\right)
$$

ゆ完に（6）式を（7）式に代入すると

$$
\Phi(c)=\frac{4 c}{\pi E} \sigma_{y}\left(\frac{a}{c}-1\right)=\frac{\pi \sigma^{2} c}{2 E} \cdot \frac{1}{\sigma_{y}}
$$

となり，破壊の発生は $\Phi(c)$ が $\Phi_{c r i t}$ になることである。

Griffith-Orowan のエネルギー条件式である（1）式の塑性表面エネルギーS 破壊の発生の場合を考完て $S_{\text {。 }}$ と拈くと，(1）式拈よび（8）式より 


$$
S_{i}=\sigma_{y} \Phi_{c r i t}
$$

が得られる。したがつて, 破壊の発生の場合は塑性表面エネルギー $S_{i}$ は龟裂先端の部分が相当の範囲に降伏を 怙こし，Bilby らの塑性変位の限界值に $\sigma_{y}$ を乗じた仕事量に等しいるのと考えることができる。

なお，Wells による開口変位との関係をもとめると， $G=2 S_{\imath}$ であるから（2）式より

$$
\delta=\frac{8}{\pi} \Phi_{c r i t}
$$

が得られる。

鋼板の破壊発生特性をもとめるには Bilby らによる亀裂先端における塑性変位 $\Phi(c)$ を実测し，その温度依 存性をしらべる必要があるが，工学的手法として塑性表面エネルギー $S_{i}$ をるめる方が実験的に容易である。

\section{3 deep notch test による破壊発生特性の無限板の場合への拡張}

general yielding を括こさない場合の脆性破壞発生時の塑性表面エネルギー $S_{i}$ の温度依存性をもとめるには 秋田，池田ら1)の deep notch test をもちいればよい。

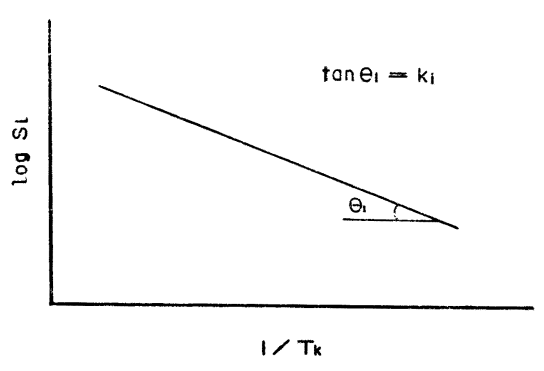

第 2 図 塑性表面エネルギーと絶対温度の関係

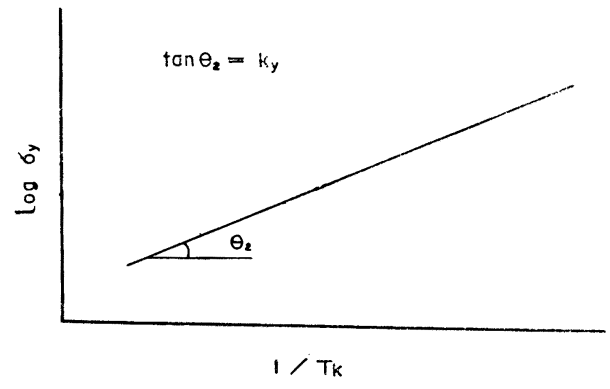

第 3 図降伏点と絶対温度の関係

両者の間には第 2 図の直線関係があり, 次式によりあらわされる1)2)。

$$
S_{i}=S_{0 i} e^{-k_{i} / T K}
$$

ただし， $S_{0 \imath}, k_{\imath}=$ 材料定数, $T_{K}=$ 絶対温度

また降伏点と温度の間にも第 3 図に示す直線関係があり，次式であらわされる。

$$
\sigma_{y}=\sigma_{0 y} e^{k y / T_{K}}
$$

ただし， $\sigma_{0 y}, k_{y}=$ 材料定数

いま, 安全率を $n$ とし, ある温度での応力をそのときの降伏点にたいして定めると次式の関係がある。

$$
\sigma=\frac{1}{n} \sigma_{y}, \quad n>1
$$

(11)，(12)，(13) 式を（1）式に代入すると

$$
e^{\frac{k_{i}+2 k y}{T_{K}}}=A n^{2} \frac{1}{c}
$$

ただし

$$
A=\frac{2 E}{\pi} \cdot \frac{S_{0 i}}{\sigma_{0 y}{ }^{2}} \quad \text { (単位 } \mathrm{mm} \text { ) }
$$

(14) 式はつぎのように書き直すことができる。

$$
\frac{k_{\imath}+2 k_{y}}{T_{K}}=\log A+2 \log n-\log c
$$

(11)，(12) 式を実験からもとめて拉げ (15) 式の $A$ も計算でき，したがつて任意の安全率 $n$ および亀裂長さ $2 c$ にたいする破懐発生温度は（14）式からもとまるわけで図的には第 4 図からすとめられる。

最近, 池田がもちいている deep notch test 試験片は第 5 図に示するのである。いま, 切欠深さを $c$, 試験片 のウを $2 b$ であらわし

$$
c / b=r
$$


とおく。有限巾の試験片の場合のエネルギー条件式は（1）式ののの代りに，切欠のない断面の応力，すなわち gross stress $\sigma$ に切欠深さと試験片の半巾の比， $\gamma$, の函数である修正係数を乗じた修正応力るるちいる。修正 倸数は次式であらわされる。

$$
\begin{aligned}
& f(\gamma)=\sqrt{\frac{2}{\pi \gamma} \tan \frac{\pi \gamma}{2}+0.1 \sin \pi \gamma, \quad \text { (両側切欠の場合) }} \\
& f(\gamma)=\sqrt{\frac{2}{\pi \gamma} \tan \frac{\pi \gamma}{2}, \quad \text { (片側切欠の場合) }}
\end{aligned}
$$

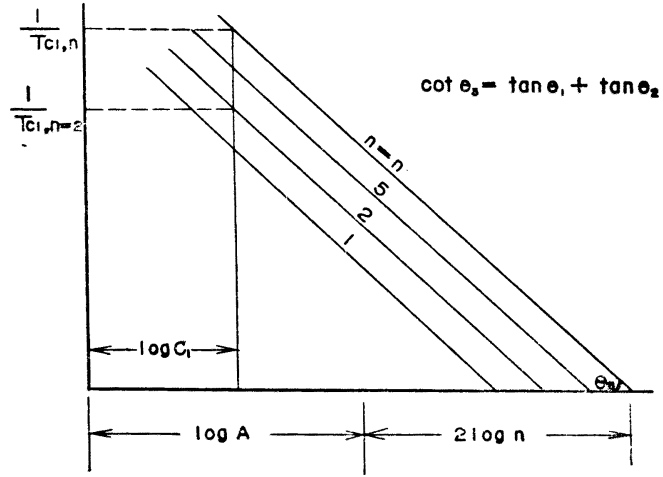

第 4 図 脆性破壞発生温度のもとめ方

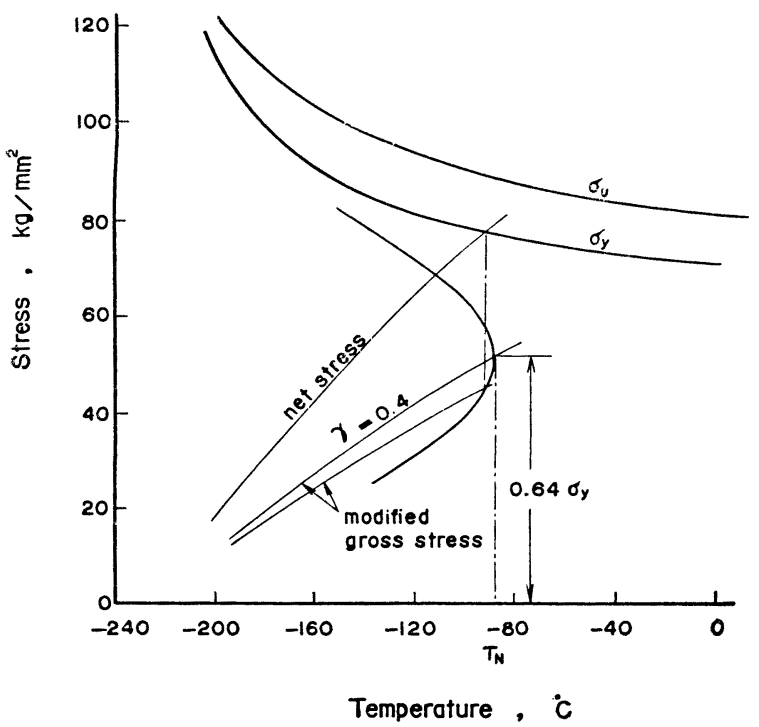

第 6 図 nose temperature, $T_{N}$. のもとめ方
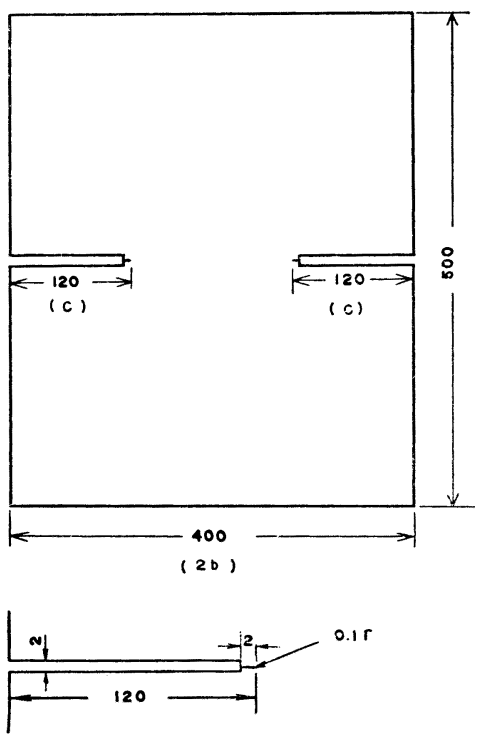

第 5 図 deep notch test 試験片 および切欠部詳細

deep notch test による脆性破壞発生特性図 （第6図）で右に凸の曲線，すなわち general yielding 限界曲線（この曲線上の温度で, 種々 の切欠深さの場合に general yielding が生じ, この曲線の左側が低応力で脆性破壞が発生する 領域を示す。）は試験片の巾の影響をうけ，そ の突端の温度 $T_{N}$ (nose temperature と名付 ける）は鋼板の脆性破罜発生特性をあらわす特 性值の一つであると考えられる。

この $T_{N}$ はつぎのようにしてもとめられる。 general yielding は破壊時の net stress が その温度での降伏点に等しくなると生ずると簡

単に考えると（この仮定は有限巾の試験片の場合，十分には正確でないことを後に述べる。），gross stress $\sigma$ net stress $\sigma_{0}$ の関係をるちいて次式が得られる。

$$
\sigma_{y}=\sigma_{0}=\sigma /(1-\gamma)
$$

(13) 式ののの代りに修正係数を乗じた $f(\gamma) \cdot \sigma$ をるちい，(19) 式を代入すると

$$
\frac{1}{n}=f(\gamma)(1-\gamma)
$$

(17) 式と（18）式の差は小さいので計算の簡単化のために（18）式をもちいる。(20) 式を（14）式に代入する c 


$$
e^{\frac{k_{i}+2 k y}{T_{K}}}=A \cdot \frac{1}{b} \cdot \frac{1}{F(\gamma)}
$$

ただし，

$$
F(\gamma)=f^{2}(\gamma) \cdot(1-\gamma)^{2} \cdot \gamma
$$

(21) 式は general yielding 限界曲線をあらわす右に凸の曲線の式である。この式よりあきらかなようにbが 大さいほど，すなわち広巾になるほど破壞発生温度 $T_{K}$ は高温に なり実験が容易になる。第 6 図の $T_{N}$ は $(21)$ 式の $T_{K}$ を最大 にする温度であるから右辺の $F(\gamma)$ が最大になる点である（第 7 図)。すなわち

$$
\frac{d F(\gamma)}{d \gamma}=0
$$

したがつて (18), (22) 式より

$$
\frac{\pi}{2}(1-\gamma)=\sin \pi r
$$

これを解くと

$$
r=0.4
$$

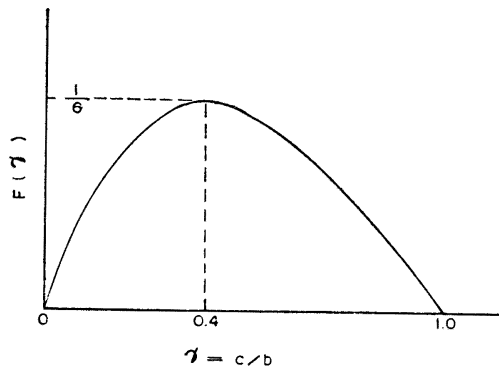

第 7 図 $F(\gamma)$ と $\gamma$ の関係

のとき最大になり，その場合には

$$
F(\gamma)=1 / 6
$$

ゆ觉に (19) 式より gross stress は

$$
\sigma=0.6 \sigma_{y}
$$

となり，修正応力であらわすと（18）式より

$$
f(\gamma) \cdot \sigma=0.64 \sigma_{y}
$$

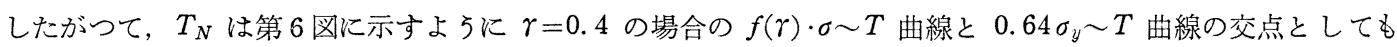
とめられる。

$T_{N}$ に括いては $F(\gamma)=1 / 6$ なるゆえ (21) 式に代入して

$$
e^{\frac{k_{i}+2 k y}{T N}}=\frac{6}{b} A
$$

(28) 式の $A$ を無限板の場合の (14) 式に代入すると

$$
\frac{1}{T_{K}}-\frac{1}{T_{N}}=\frac{1}{\left(k_{i}+2 k_{y}\right)} \log \left(\frac{n^{2}}{6} \cdot \frac{b}{c}\right)
$$

しかるに $T_{N}$ では $c / b=0.4$ なる故

$$
\frac{1}{T_{K}}-\frac{1}{T_{N}}=\frac{1}{\left(k_{\imath}+2 k_{y}\right)} \log \left(\frac{n^{2}}{2.4}\right)
$$

いま，簡単化のために $n=2.56$ とおくと

$$
\frac{1}{T_{K}}=\frac{1}{T_{N}}+\frac{1}{\left(k_{\imath}+2 k_{y}\right)}
$$

この式は deep notch test で $T_{N}$ がもとまると, 無限板に $2 c$ の亀裂が存在するときの, 安全率 $n=2.56$ の 場合の破壞発生温度 $T_{K}$ (絶対温度) がもとめられることを意味している。

なお，試験片の巾がせまくて general yielding をおこさないで実験することが困難な場合には $T_{N}$ がもとめ にくい。その場合は巾 $5 m c$ の広巾試験片で亀裂長さも $m$ 倍 $(\boldsymbol{r}=0.4)$ の試験片で実駼すればよい。この場合 の $T_{N}$ を $T_{N m}$ とすれば, $(28)$ 式より

$$
\frac{1}{T_{N}}-\frac{1}{T_{N m}}=\frac{1}{\left(k_{\imath}+2 k_{y}\right)} \log m
$$

要するに広巾試験片によつて比較的高温の $T_{N m}$ をもとめれば $(30)$ 式から $T_{N}$ が容易にもとめられる。著者 は $m b=200 \mathrm{~mm}, m c=80 \mathrm{~mm}$ を標準試験片としている。(29) 式の $T_{N}$ に $(30)$ 式の $T_{N}$ を代入すると

$$
\frac{1}{T_{K}}-\frac{1}{T_{N m}}=\frac{1}{\left(k_{i}+2 k_{y}\right)} \log \left(\frac{n^{2} m}{2.4}\right)
$$

要するに，標準試験片をもらいれば $T_{N m}$ がもとめられ，考えるべき亀裂長さ $2 c$ をきめれば $m(=80 / c)$ がも 


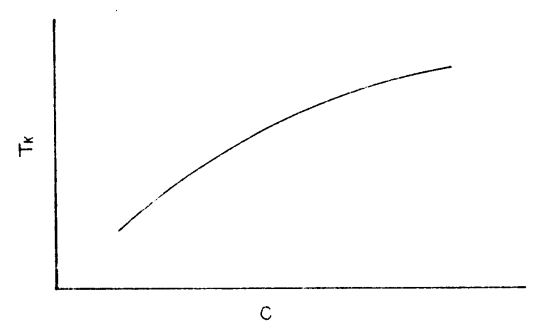

第 8 図亀裂長さと脆性破壊温度発生の関係

とめられ, 限伏点にたいする安全率 $n$ をあたえれば破壞発生温 度 $T_{K}$ (絶対温度) は (31) 式から容易にもとめられる。

実際の計算の便のため, (31) 式で $n=2.56$ と特くと

$$
T_{K}=\frac{T_{N m} \cdot\left(k_{i}+2 k_{y}\right)}{\left(k_{i}+2 k_{y}\right)+T_{N m}(1+\log m)}
$$

すなわら, 種々の亀裂長さ $2 c$ で $n=2.56$ の場合の脆性破壞 発生温度 $T_{K}$ を $(32)$ 式よりもとめると第 8 図の関係が得ら れる。

$T_{K}$ は前述の $(14 \mathrm{~A})$ 式および (15) 式よりもとめることが できるが，鋼板の脆性破壊発生特性をあらわす一つの特性值と して標準試験片の nose temperature, $T_{N m}$ ，を採用するのがよいと考えられ，これを利用して $T_{K}$ をもとめた のが (32) 式である。

\section{4. 実 験 的研 究}

実験的研究として，まず deep notch test の破壞発生特性についての基礎的研究として（1）破壞の分類， （2）エネルギ一条件式の適用，（3）切欠先端部の塑性域の大きさ，（4）板厚効果を調查し，つぎに現用の各 種鋼板の脆性破壊発生特性の評価の研究として（1）軟鋼，（2）各種高張力鋼，（3）各種低温用鋼についてし らべ，他の大型および小型試験の諸遷移温度との関連もしらべた。

\section{1 供 試 材}

基礎的研究の $(1) \sim(3)$ 項用の供試材として, 板厚 $25 \mathrm{~mm}$ のセルキルド軟鋼（鋼 $\mathrm{Q}$ ), 60 キロ高張力鋼 (鋼 R)，（4）項用として板厚 $45 \mathrm{~mm}$ の HY 80 鋼（鋼 S ）をもちいた。

つぎに現用鋼板の材質評価のために，板厚が主として $20 \mathrm{~mm}$ 抢よび $25 \mathrm{~mm}$ のキルド軟鋼（鋼 $\mathrm{A} ） ， 60 ， 70$, 80, 100 キロ高張力鎆 (WES-HW 36 ないし HW 90), (鋼 Bないし鋼 I ), 降伏点が 33, 37, 58 キロ級の調質

第 1 表 化学成分执よび機械的性質

\begin{tabular}{|c|c|c|c|c|c|c|c|c|c|c|c|c|c|c|c|c|c|c|}
\hline \multirow[b]{2}{*}{ Steel } & \multirow{2}{*}{$\begin{array}{l}\text { Kind } \\
\text { of } \\
\text { Steel }\end{array}$} & \multirow{2}{*}{$\begin{array}{l}\text { Plate } \\
\text { Thick }\end{array}$} & \multicolumn{13}{|c|}{ Chemical Compositions } & \multicolumn{3}{|c|}{$\begin{array}{l}\text { Mechnical } \\
\text { Properties }\end{array}$} \\
\hline & & & $\mathrm{C}$ & $\mathrm{Si}$ & $\mathrm{Mn}$ & $\mathrm{P}$ & $\mathrm{S}$ & $\mathrm{Cu}$ & $\mathrm{Ni}$ & $\mathrm{Cr}$ & Mo & $\mathrm{V}$ & B & A1 & $\mathrm{N}_{2}$ & $\begin{array}{l}\text { Y.P. } \\
\mathrm{kg} / \\
\mathrm{mm}\end{array}$ & $\mid \begin{array}{l}\text { T.S. } \\
\mathrm{kg} / \\
\mathrm{mm}\end{array}$ & $\underset{\%}{\text { Elong }}$ \\
\hline A & $\begin{array}{c}\text { Normalized } \\
\text { Killed }\end{array}$ & 20 & 0.20 & 0.23 & 0.71 & 0.015 & 0.027 & & & & & & & & & 25.1 & 41.1 & 32.6 \\
\hline B & HW $\begin{array}{ll}36 \\
(\mathrm{HT}\end{array}$ & 20 & 0.17 & 0.53 & 1.24 & 0.013 & 0.011 & 0.22 & 0.11 & 0.14 & & & & & & 38.6 & 63.5 & 31.0 \\
\hline C & $\begin{aligned} \text { HW } & 40 \\
& (\mathrm{HT} \quad 60)\end{aligned}$ & 25 & 0.14 & 0.29 & 1.23 & 0.011 & 0.003 & 0.10 & & & & 0.08 & & & & 49.7 & 59.1 & 19.0 \\
\hline $\mathbf{D}$ & HW 63 & 20 & 0.16 & 0.36 & 0.92 & 0.012 & 0.013 & 0.80 & 0.38 & 0.21 & 0.35 & & & & & 69.8 & 79.4 & 35.3 \\
\hline $\mathbf{E}$ & $\begin{array}{ll}\mathrm{HW} & 50 \\
& (\mathrm{HT}\end{array}$ & 25 & 0.15 & 0.30 & 1.13 & 0.012 & 0.005 & 0.24 & 0.82 & 0.40 & 0.26 & 0.026 & 60.0028 & 0.014 & & 64.5 & 73.9 & 19.0 \\
\hline F & $\begin{aligned} \text { HW } & 70 \\
& (\mathrm{HT} \\
& 80)\end{aligned}$ & 19 & 0.15 & 0.26 & 0.75 & 0.013 & 0.009 & 0.28 & 1.38 & 0.61 & 0.48 & 0.07 & 0.0014 & & & 76.3 & 81.7 & 22.5 \\
\hline G & $\begin{array}{ll}\text { HW } & 80 \\
& (\mathrm{HT}\end{array}$ & 20 & 0.15 & 0.24 & 1.28 & 0.022 & 0.013 & 0.23 & 0.23 & 0.50 & 0.49 & & & 0.003 & 0.002 & 73.8 & 83.4 & 16.0 \\
\hline $\mathrm{H}$ & $\begin{array}{r}\text { HW } 90 \\
\text { (HT 100) }\end{array}$ & 25 & 0.15 & 0.25 & 0.82 & 0.009 & 0.007 & 0.24 & $|0.93|$ & 0.54 & 0.54 & 0.06 & & & & 98.2 & 102.3 & 20.0 \\
\hline I & HW 90 & 13 & & & & & & & Ditto & & & & & & & 98.7 & 102.1 & 23.9 \\
\hline $\mathbf{J}$ & QT A1-Kill. & 25 & 0.10 & 0.26 & 1.18 & 0.010 & 0.003 & & & & & & & & & 38.6 & 49.1 & 29.8 \\
\hline $\mathrm{K}$ & QT A1-Kill. & 20 & 0.11 & 0.25 & 1.25 & 0.001 & 0.008 & 0.57 & & & & & & & & 37.0 & 51.6 & 45.0 \\
\hline L & $\begin{array}{l}\text { QT Al-Kill. } \\
58\end{array}$ & 25 & 0.10 & 0.18 & 0.54 & 0.010 & 0.009 & & 2.50 & 0.35 & 0.41 & & & & & 61.2 & 68.4 & $\overline{31.2}$ \\
\hline M & $2.5 \% \mathrm{Ni}$ & 20 & 0.09 & 0.27 & 0.55 & 0.009 & 0.008 & 0.50 & 2.55 & 0.035 & 0.006 & & & 0.010 & 0.0092 & 37.1 & 47.5 & 31.0 \\
\hline $\mathrm{N}$ & $3.5 \% \mathrm{Ni}$ & 20 & 0.06 & 0.30 & 0.51 & 0.011 & 0.007 & & 3.53 & & & & & 0.027 & & 38.2 & 49.3 & 30.0 \\
\hline $\mathrm{P}$ & $9 \% \mathrm{Ni}$ & 20 & 0.07 & 0.20 & 0.48 & 0.008 & 0.017 & 0.18 & 8.54 & & & & & 0.017 & 0.011 & 67.2 & 71.0 & 25.5 \\
\hline $\mathbf{Q}$ & Semi Killed & 25 & 0.19 & 0.07 & 0.71 & 0.022 & 0.015 & & & & & & & & & 27.0 & 45.0 & 26.0 \\
\hline $\mathrm{R}$ & $\begin{array}{l}\mathrm{HW} \\
\quad \mathrm{HT}\end{array}$ & 25 & 0.15 & 0.40 & 1.28 & 0.025 & & & & & 0.26 & 0.06 & & & & 53.0 & 65.0 & 18.0 \\
\hline $\mathrm{S}$ & $\begin{array}{r}\mathrm{HW} 63 \\
(\mathrm{HY} 80)\end{array}$ & 45 & 0.11 & 0.28 & 0.30 & 0.014 & 0.006 & 0.08 & 2.91 & 1.30 & 0.39 & & & 0.009 & & 76.6 & 82.4 & 45.0 \\
\hline
\end{tabular}


アルミキルド鋼（鋼 J, K, L) 扣よび 2.5，3.5，9\% Ni 鋼（鋼 M. N.P）の低温用鋼をもちいた。な特，鋼H と鋼 I は同一チャージの 100 キロ IN 処理鋼で板厚がことなる。な拉, 鋼Cないし鋼 $\mathrm{G}$ は調質型の高張力鋼で める。これらの化学成分拉よび機械的性質を第 1 表に示す。

\section{2 試験片および試験方法}

試験結果の解析に, 降伏点扣よび抗張力と温度の関係が必要であるので, 平行部の直径が $6 \mathrm{~mm}$ の丸棒引張試 験片をるちい, $-196^{\circ} \mathrm{C}$ ない室温の数温度で引張試験を机こなう。

deep notch test 試験片は第 5 図に示すように $500 \mathrm{~mm} \times 400 \mathrm{~mm}$ の寸法で切欠深さは $120 \mathrm{~mm}$ を主とし, 切 欠深さの影響の研究には $40 \mathrm{~mm}$ 括よび $80 \mathrm{~mm}$ を追加する。切欠は先端部に巾 $0.2 \mathrm{~mm}$, 深さ $2 \mathrm{~mm}$, 先端半 径 $0.1 \mathrm{~mm}$ の鋭い切欠がつけられている。これが自然龟裂と同程度の鋭さのすのとみなしらるかどかについ て後述の実験を扣こない，十分の鋭さがあるという結論が得られている。

試験片をタブに溶接したのち, 船舶技術研究所船体構造部の 300 ton 構造物試験機にとりつけ, 試験温度に一 定時間保持したのち引張荷重を加えて破断させる。冷剤として液体窒素, ドライアイス, アルコール, イソペン タン等がもらいられる。

また破壞時の切欠先端部の塑性域の大きさをしらべるために応力分布を計測する必要があるので, 100 キ口高 張力鋼（鋼 I, 板厚 $13 \mathrm{~mm}$ ) の試験片の切欠断面上に標点距離 $10 \mathrm{~mm}$ の歪ゲージを片面に 13 枚, 裏面に 7 枚 贴付する。

\section{3 試験結果および解析}

4.3.1 破壊の分類：第 1 報に执いて，低応力脆性破壊が生ずるのは第 6 図の general yielding 限界曲線の 低温側の領域であると述べた。後述のように，軟鋼ではこの限界曲線がかなり低温部に位置しており，これまで の常識的に「軟鋼は脆性破壊しやすい」という概念と相容れない感じがするので, 軟鋼拉よび高張力鋼の代表例 としての 60 キロ高張力鋼の両者について general yielding 限界曲線より高温部での破壊の挙動をしらべた。

まず, 板厚 $25 \mathrm{~mm}$ の七ミキルド鋼（鋼Q）について, $-182 \sim 30^{\circ} \mathrm{C}$ の種々の温度で, 切久深さが 40,80 , $120 \mathrm{~mm}$ の試験片を引張つて破壊させた。破壊荷重より net stress, gross stress 扰よび有限巾の修正をした modified gross stress をもとめ, 温度との関係をるとめると第 9 図に示すようになる。

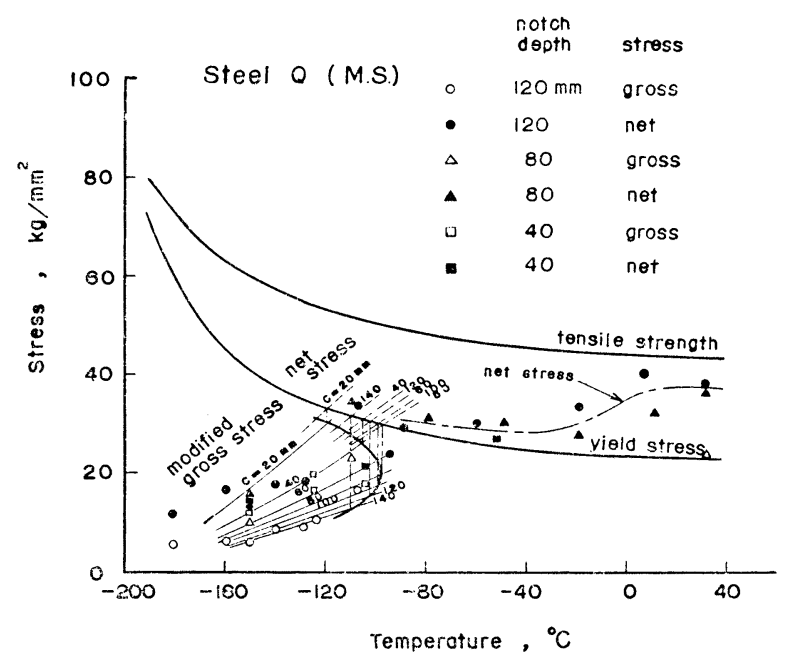

第 9 図軟鋼（銅 Q）の破壤発生特性

図より, general yielding 限界曲線の低温側では, 切久深さによりことなるが, net stress はいずれる降伏 点より低い, いわゆる低応力脆性破壞が生じて特り, その破面は写真 1 (a) 飞示すように脆性破面であつて切 欠底部にも何らの延性破面が存在していない。この領域を (1) と名付ける。

general yielding 限界曲線より高温側では, 切欠深さの大きさいかんにかかわらずほぼ 1 本の net stress-温 


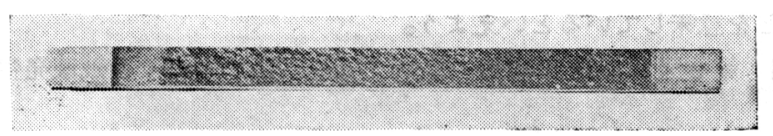

(a) B.F. without G. Y. (Zone I )

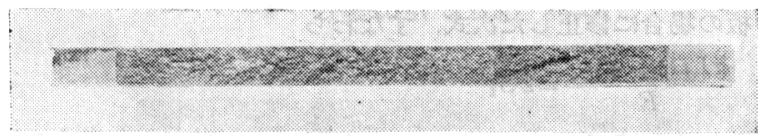
B. F. $=$ Brittle Fracture
D. F. = Ductile Fracture
G. Y. = general Yielding

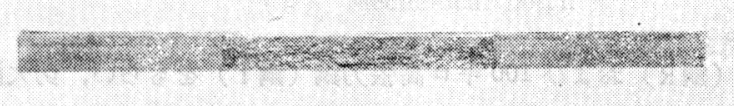

(c) Mixture of D.F. and D.F. (Zone III)

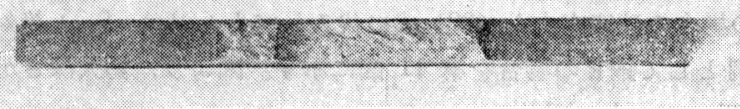

(d) D.F. (Zone III)

写真 1 破面 $($ 鋼Q)

度曲線が得られ, net stress は降伏点より僅かだけ高くなつている。その破面は写真 1 (b)に示すように (1) と同様に脆性破面であり，かつ shear lip も切欠底部の延性破面もみられない。この領域を(1) と名付ける

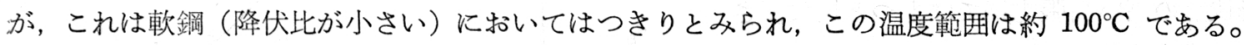

さらに高温側では, 切欠深さのいかんにかかわらず net stress は抗張力に近い值になり, その破面は領域 (11) からの遷移部で写真 1 （c）に示すよ5に切欠底部に小さい三角形の延性破壊が生じたのち, 脆性破壞に变化す る。も5少し高温部では全断面にわたつて延性破壞が生じている。この領域を 囵と名付ける。

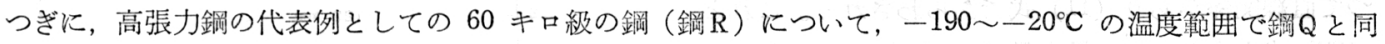
様に切久深さが $40,80,120 \mathrm{~mm}$ の試験片を破壞させ，その結果を第 10 困に示す。

軟鋼の場合と比較して顕著な特徵をみると, 領域 (10, すなわち general yielding してから脆性破壊の生ずる 領域が注とんど存在せず, 低応力脆性破壞の領域 (1) から, net stress が抗張力に注洔しくて延性破壊する領 域 (11) に直接接続しているとみなすことができる。すなわち, general yielding 限界曲線が脆性破壊領域と延性

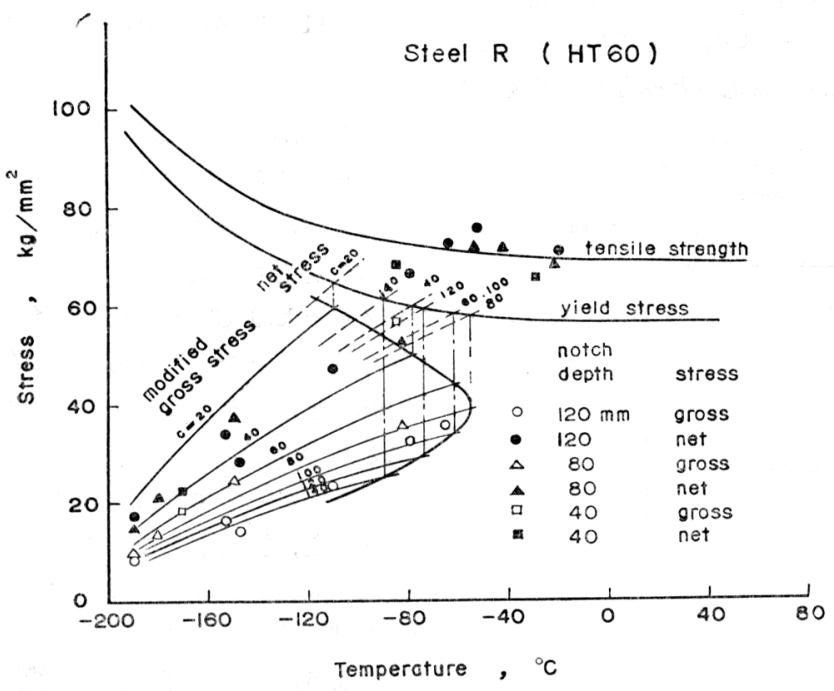

第 10 図 60 キ口高張力銅 (鋼R) の破壊発生特性 
破壊領域の境界になつていることを意味しているといえよう。

4.3.2 エネルギ条件式の適用: 第 9 図扣よび第 10 図の低応力脆性破壊の領域での破壊発生条件について梌討 する。

第 1 報に执いて，この領域では無限板の場合の Griffith-Orowan のエネルギー条件式である（1）式を(17) 式の修正係数をむちいて有限巾の板の場合に修正した次式, すなわち

$$
\frac{\pi[f(\gamma) \cdot \sigma]^{2} c}{E}=2 S_{i}
$$

が脆性破壊の発生条件として適用されると述べたが, net stress が降伏点に近づいた場合や切欠深さが短い場合 についても, 第 2 図に示されている直線性が成立するかどうか, 招よび同一温度では塑性表面エネルギーが同一 值になるかという疑間が出された。

ここでは軟鋼（鋼Q），60 キロ（鋼R）拈よび 100 キロ高張力鋼（鋼 I ）をるちい，切欠深さを $40 ， 80,120$ $\mathrm{mm}$ (第 1 報では $100,140,180 \mathrm{~mm}$ ) に変化させ, general yielding の温度附近をで実験を括こなつた。鋼Q 抢よび鋼 $\mathrm{R}$ の場合の破壞応力と温度の関係は第 9 図拉よび第 10 困に示されている。

切欠深さが $40,80,120 \mathrm{~mm}$ の場合の破壞応力を(33) 式に代入してもとめた $S_{\imath}$ と絶対温度 $T_{K}$ の関倸を 各鋼についてもとめたが, その 1 例として鋼 $\mathrm{R}$ の場合を第 11 図に示す。図より, 切欠深さが変化しても, ほぼ 本の直線であらわせること, 特よび general yielding のすぐ近くの温度まで直線関係がみとめられることが わかる。

な扮軟鋼（鋼Q）の場合に，切欠深さが $40 \mathrm{~mm}$ で も前記の直線関係が成り立つていることから推定する と, さらに降伏点の高い高張力鋼ではもつと切欠深さ の短い場合まで成立する可能性があるといえよう。

したがつて, 領域 (1)では (33) 式ですとめた $S_{i}$ と 絶対温度 $T_{K}$ の間に切欠深さのかなり広い範囲にわた つて直線関係があり (11) 式であらわされる。これと

(33) 式をもちいて, 最小限 2 枚の deep notch test 試験片により, 種々の切欠深さの場合の破壞応力と温 度の関係をるとめることができる。

Griffith-Orowan の式は長さが $2 c$ の亀裂が存在す る場合のエネルギー条件式であり, deep notch test によりもとめられる破壞応力-温度曲線は, 先端半径 が $0.1 \mathrm{~mm}$ の機械的切欠にたいするるのである。した がつて，この鋭い切欠が自然亀裂とみなしうるもので

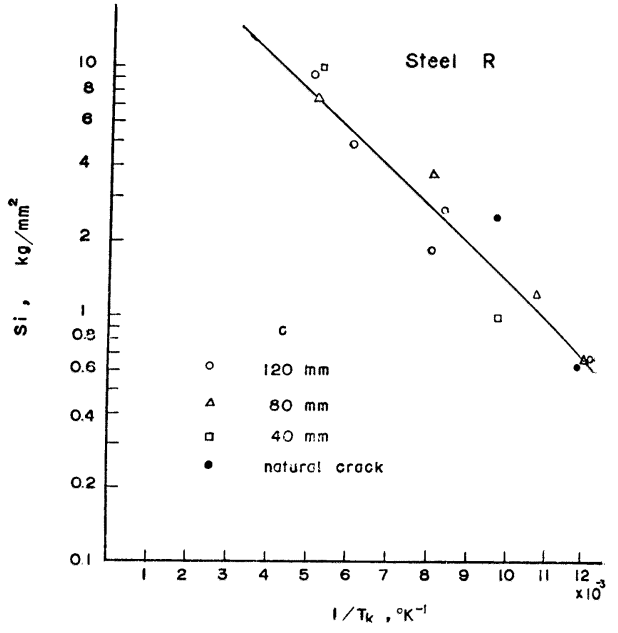

第 11 図 塑性裴面エネルギーと絶対湿度の闺係

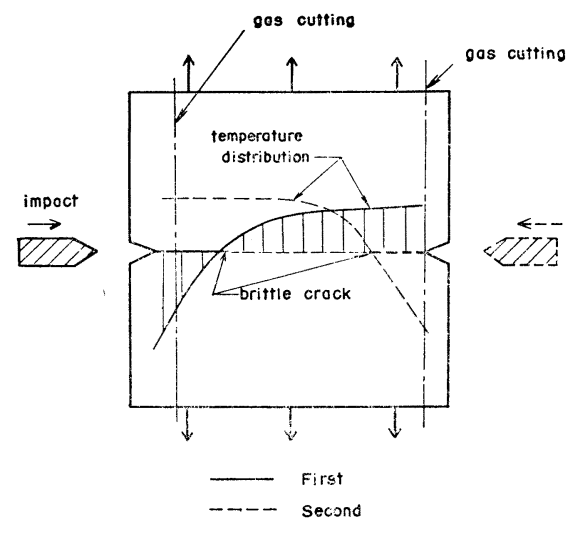

第 12 図自然亀裂のつけナj

あるかどらか検討して打くことは（33）式等をもちいて現 象をしらべるためには必要である。

本研究では陚験片の両外側に自然龟裂をつけるためにつ ぎの方法をもちいた。まず，第 12 図に示すように両外側 にVノッチ拉よびその先端半径が $0.1 \mathrm{~mm}$ である $\mathrm{ESSO}$ 試験片型のノッチをつける。試験片の巾は大きめにして $500 \mathrm{~mm}$ とし, タブにとりつけたのち 300 ton 構造物試験 機にとりつける。

第 12 図に示す上 布をあたえ, 楔をらちこんで脆性龟裂を発生, 停止させ, 最後に左右対称，かつ巾が $400 \mathrm{~mm}$ になるようにガス切 断して試験片をつくつた。

このようにしてつくつた自然龟裂つき試験片の破壊応力 から塑性表面エネルギーをもとめると, 銅 Rの場合第 11 


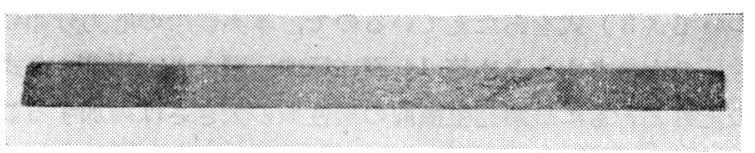

(a) Natural crack (notch)

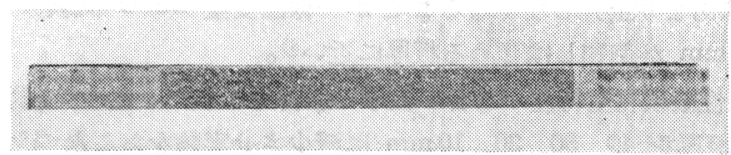

(b) Mechanical notch

写真 2 自然龟裂と機械的切欠の先端形状

図の黒丸で示す值が得られ，先端半径が $0.1 \mathrm{~mm}$ の機械的切欠でもとめた值とめまり大差のないことがわかる。 図中の直線より上飞位置しているのは写真 2 亿示す上 5 亿, 自然龟裂の先端が機械的切欠の場合の上5に直線状 でなくて幾分抛物線状になつて括り，いくらか破壞が発生しにくいためで女らうと考觉られる。

要するに，本実験により鋼Rのみならず鋼 $\mathrm{I}$ のような 100 キ口高張力や軟鋼（鋼Q）飞物いても，先端半径が $0.1 \mathrm{~mm}$ の機械的切欠でもとめる脆性破壞発生特性は自然亀裂からの脆性破壞の発生特性をあらわしているとみ なしてよいことがわかつた。

4.3.3 切欠先端部の塑性域の大きさ：亀裂を有する鋼板を引張ると，亀裂先端部に塑性域が生じ，それがあ る大きさに達してから破壊が発生する。前述の Wells もBilby らもいずれもこの塑性域の大きさに注目し，そ れと亀裂先端の開口变位あるいは塑性变位との関係をもとめている。

本実験では，切欠先端部に生ずる塑性域の大きさをるとめるために，破壞が発生する直前の弾性応力分布とそ の温度での降伏点の大きさからもとめた。しかし, 塑性変形が切欠先端部に生ずると力の平衝のため塑性域は

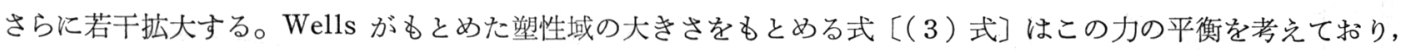
それによる場合は単純に弹性応力分布で降伏点を越える大きさの応力が存在する範囲を塑性域とみなした場合よ り大きいことが予想される。

ここでは弾性応力分布をもとめるために，降伏点の高い 100 キ口高張力鋼で切欠深さが $120 \mathrm{~mm}$ の deep notch test 試験片を室温で引張つた。第 13 図は種々の応力レベルの場合の応力分布を示し, 中央部の応力が荷 重と断面積から計算でもとめられる平均応力 (mean stress) 上り小さく, 平均応力が大きくなるとその差は增 加している。

本実験では鋼 $\mathrm{Q}$ 㧍よび鋼 $\mathrm{R}$ にいて種々の温度での破壞応力（net stress）が判明しているので，そのときの 弾性応力分布を第 13 図からもとめ, その温度での降伏点で応力曲線を切り塑性域の大きさと乙第 14 図涂す。

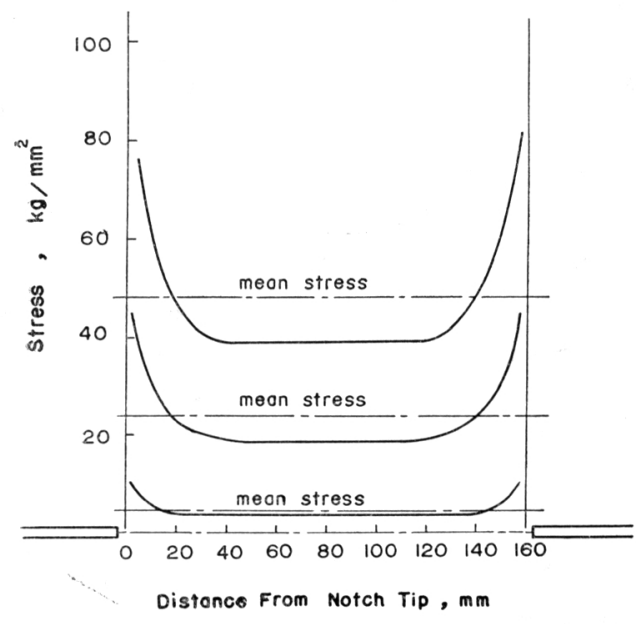

第 13 弾図性応力分布 (切欠深さ $120 \mathrm{~mm}$ の場合)

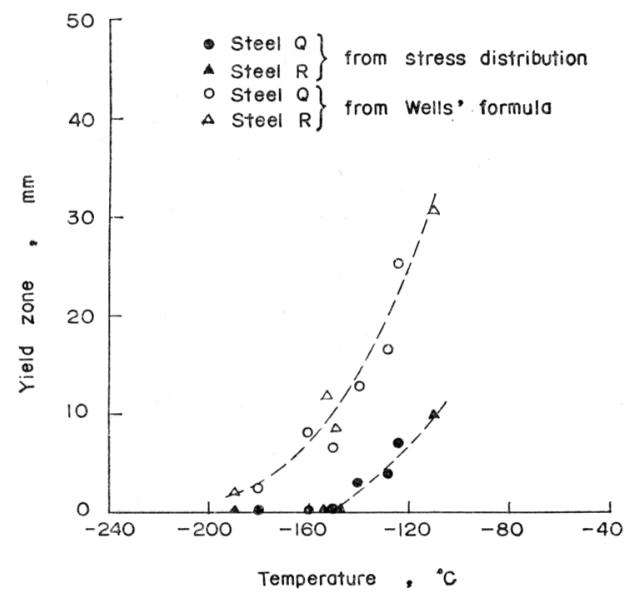

第 14 図切欠先端部の塑性域の大きさと温度 
Wells は無限板の場合について（３）式をあたえているので, 本実験での応力分布の中央部に括ける応力をの とみなして（3）式より塑性域の大きさをもとめ第 14 図に示す。図より, Wells の式よりもとめた計算值の方 が大きいこと，抢よび温度の上昇とともに破壞発生直前の塑性域の大きさは增加することがわかる。

4. 3.4 板厚効果 : 一般に, 鋼板は板厚が増加すると脆化が著しくなり遷移温度が上昇するが, ある板厚以上 ではほぼ飽和して遷移温度はあまり上年しなくなることが一様温度型 ESSO 試験および温度勾配型二重引張試 験でしられて拉り, 板厚 $30 \mathrm{~mm}$ が飽和しはじめる板厚に近( ${ }^{8)}$ 。

deep notch test による脆性破壊発生特性の場合の板厚の影響をしらべるために, 板厚 $45 \mathrm{~mm} の H Y 80$ 鋼 (鋼 S) から機械切削により板厚を $40,30,20,10 \mathrm{~mm}$ に減少させ実験を叔こなつた。切欠深さが $120 \mathrm{~mm} の$ 試験片でもとめた破壞応力-温度曲線から（33）式を利用して $80 \mathrm{~mm}$ の場合の曲線に換算する。

前述の理論的研究でのべたように, general yielding 限界曲線の突端である nose temperature, $T_{N}$ は切欠 深さが $80 \mathrm{~mm}$ の場合の modified gross stress-温度曲線と $0.64 \sigma_{y}$-温度曲線の交点としてもとめられる。

第 15 図は板厚がそれぞれ $40,30,20,10 \mathrm{~mm}$

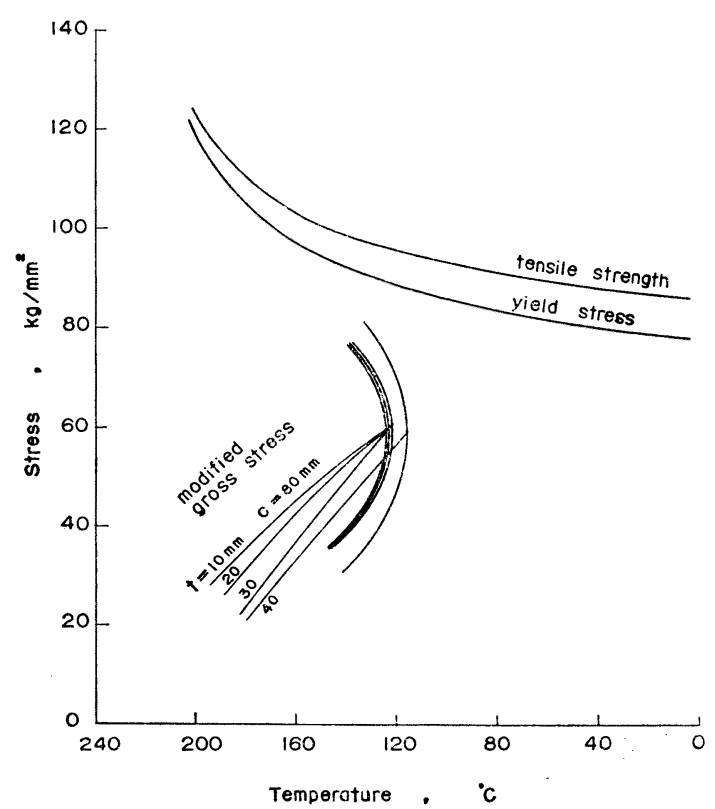

第 15 図板厚が变化する場合の脆性破壊発性特性 の場合の $T_{N}$ をとめたものである。無限板に種々 の亀裂長さが存在する場合の破壊発生温度 (絶対温. 度) は前記の $T_{N}$, 材料定数 $k_{i}, k_{y}$ と (32) 式か. らもとめることがでさる。これより龟裂長さが 10 $\mathrm{mm}$ の場合の破壊発生温度をるとめて通常の温度 $\left({ }^{\circ} \mathrm{C}\right)$ であらわし，板厚との関係をもとめると第 16 . 四に示すようになる。困より，板厚が約 $30 \mathrm{~mm}$ を

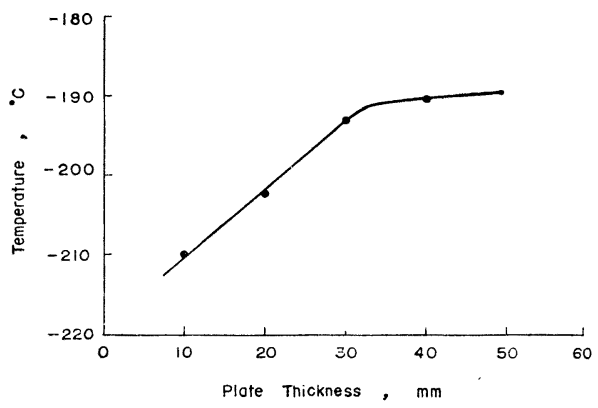

第 16 図问一亀裂長さでの脆性破壊発生温度: $(n=2.56)$ と板厚の関係

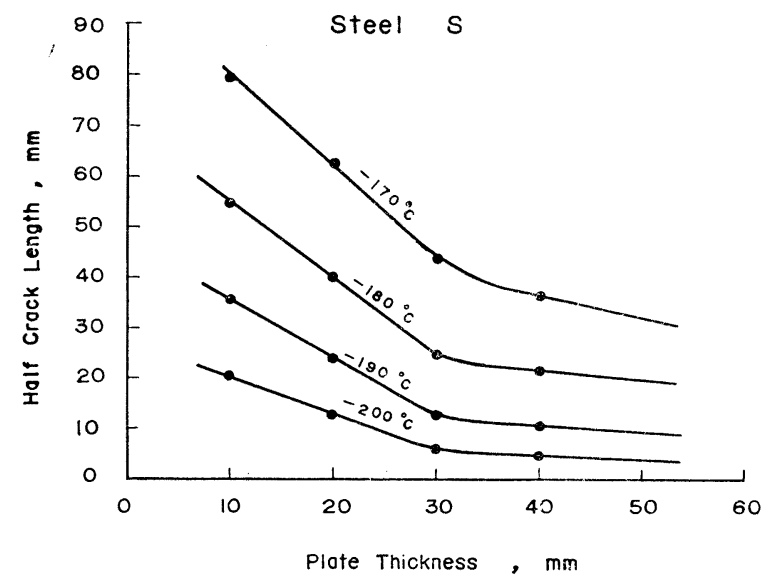

第 17 図破壊発生温度が同一の場合の亀裂長さと板厚の関係 


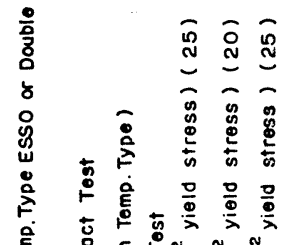

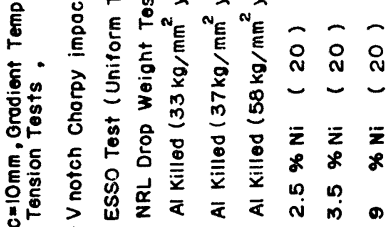

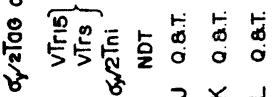
$\times 0.0 .>\leq z 0$

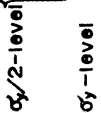
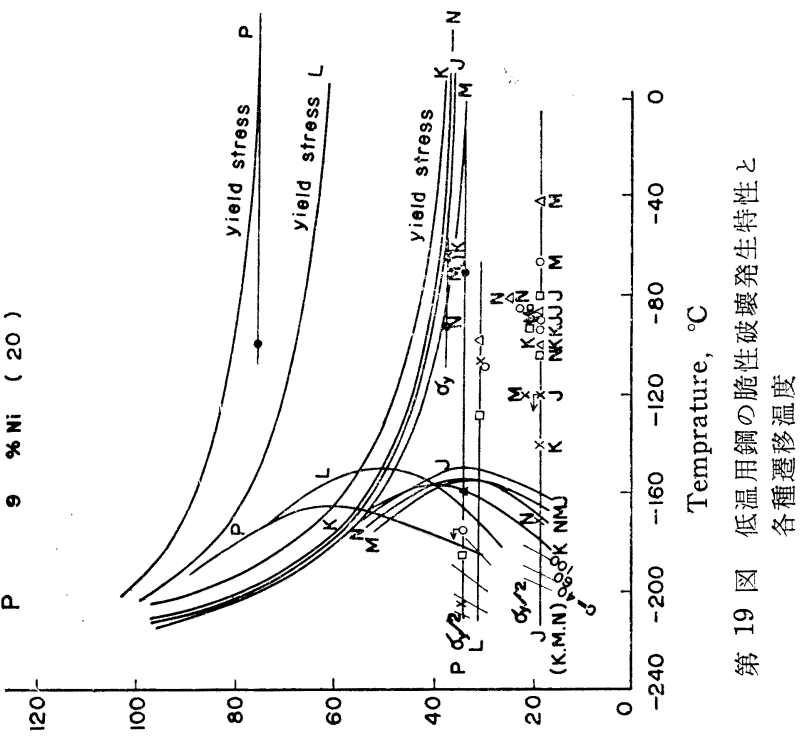

$z^{w W / O x} \cdot \operatorname{ssajts}$

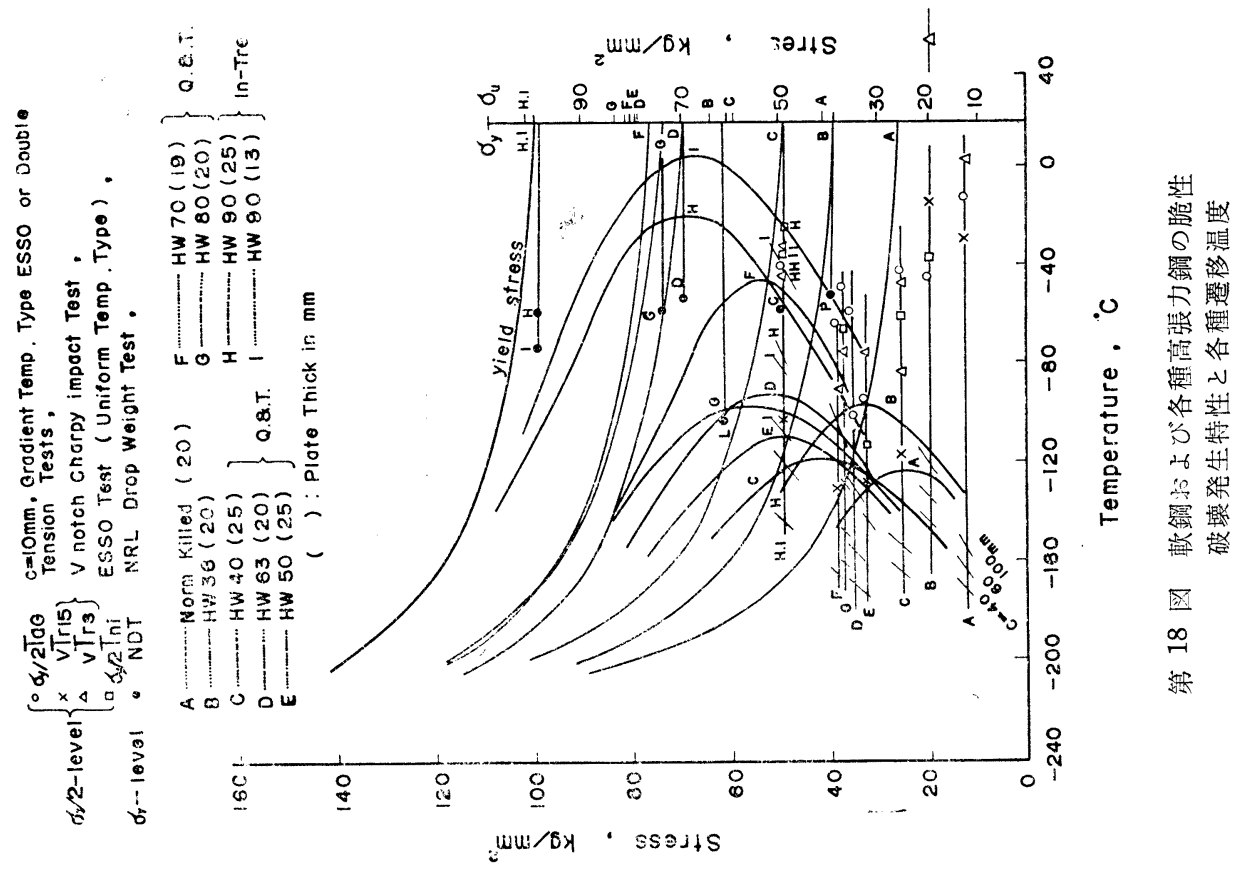


では脆性破壊発生温度は上昇し, その上昇率は $0.9^{\circ} \mathrm{C} / \mathrm{mm}$ で, 一様温度型 $\mathrm{ESSO}$ 試験の非発生温度 $T_{n i}$ の場 合の $1.2^{\circ} \mathrm{C} / \mathrm{mm}$, および温度勾配型二重引張試験の停止温度 $T_{a G}$ の場合の $1.5^{\circ} \mathrm{C} / \mathrm{mm}$ (いずれす機械切削によ る減厚）に近い8)。なお，板厚が約 $30 \mathrm{~mm}$ 以上では破壞発生温度はあまり变化しない。

つぎに，同一温度で脆性破壞が発生する場合の板厚と龟裂長さの関係を第 17 図に示す。図より，板厚が大き い注ど短い亀裂で破壞が発生することがわかる。

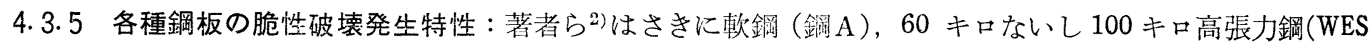
規格 HW 36 ないし HW 90, 鋼Bないし鋼 I)，特よび降伏点が 33，37，58 キロ級の調質アルミキルド鋼， $2.5 ， 3.5,9 \% \mathrm{Ni}$ 鋼などの各種低温用鋼（鋼 J ないし鋼 $\mathrm{P}$ ）についてそれぞれ第 18 図特よび第 19 図をると めた。図中には, general yielding 限界曲線や降伏点-温度曲線, 各種大型, 小型脆性破壊試験の代表的諸遷移 温度が記入されている。

第 18 図扣よび第 19 図に示す各鋼拉よび鋼 Q，Ｒ９ general yielding 限界曲線をそれぞれの温度での降伏 点をベースにして無次元化してあらわすと，これらの曲線は第 20 図に示すようになり, nose temperature の 疬力比は (27) 式で示されるように $\sigma / \sigma_{y}$ が約 0.64 のレベルに一直線上にならび理論解に良く一致しているこ

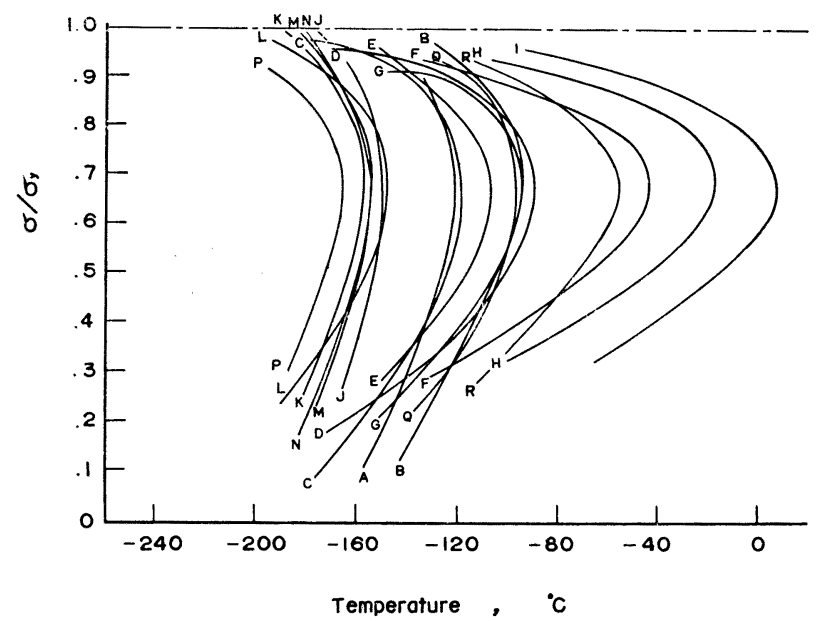

第 20 闵 無次元化した general yielding 限界油線

第 2 表 材料定数拈よび各種要移鼬度

\begin{tabular}{|c|c|c|c|c|c|c|c|c|c|c|}
\hline \multirow[b]{2}{*}{ Steel } & \multicolumn{5}{|c|}{ Material Constants } & \multicolumn{5}{|c|}{ Trasition Temperature } \\
\hline & $\underset{\mathrm{kg} / \mathrm{mm}^{2}}{S_{0 i}}$ & $\begin{array}{c}k_{i} \\
\left({ }^{\circ} \mathrm{K}\right)\end{array}$ & $\begin{array}{c}\sigma_{0 y} \\
\mathrm{~kg} / \mathrm{mm}^{2}\end{array}$ & $\begin{array}{c}k_{y} \\
\left({ }^{\circ} \mathrm{K}\right)\end{array}$ & $\begin{array}{l}T_{N m} \\
(\mathrm{C})\end{array}$ & $\begin{array}{c}T_{i} \\
(c=10)\end{array}$ & ${ }_{v} T_{r} 15$ & NDT & $T_{n i}$ & $\begin{array}{c}T_{a G} \\
(c=10)\end{array}$ \\
\hline A & 302 & 689 & 16.8 & 116 & -120 & -173 & -28 & - & - & -13 \\
\hline $\mathrm{B}$ & 766 & 876 & 28.7 & 85 & -93 & -156 & -13 & -50 & -35 & -41 \\
\hline $\mathrm{C}$ & 236 & 494 & 29.9 & 71 & -116 & -134 & -114 & -56 & -59 & -40 \\
\hline $\mathrm{D}$ & 112 & 362 & 59.3 & 46 & -88 & -191 & -108 & -51 & -98 & -55 \\
\hline $\mathrm{E}$ & 165 & 409 & 56.3 & 46 & -106 & -191 & -125 & -45 & -112 & -93 \\
\hline $\mathrm{F}$ & 54 & 274 & 65.2 & 43 & -43 & -195 & -128 & - & - & -61 \\
\hline G & 249 & 471 & 62.8 & 43 & -94 & -178 & -106 & -56 & -65 & -46 \\
\hline $\mathrm{H}$ & 108 & 359 & 73.5 & 35 & -18 & -183 & -100 & -56 & -21 & -37 \\
\hline I & 191 & 555 & 73.5 & 35 & 7 & -155 & $<-100$ & -71 & -35 & - \\
\hline $\mathrm{J}$ & 3040 & 759 & 26.9 & 74 & -150 & -186 & $<-120$ & -64 & -80 & -90 \\
\hline $\mathrm{K}$ & 165 & 347 & 27.8 & 81 & -157 & -205 & -140 & -59 & -93 & -93 \\
\hline $\mathbf{L}$ & 123 & 267 & 50.3 & 53 & -147 & -211 & -107 & - & -128 & -108 \\
\hline $\mathbf{M}$ & 2220 & 694 & 24.5 & 78 & -155 & -190 & -120 & -70 & -85 & -69 \\
\hline $\mathrm{N}$ & 208 & 405 & 27.3 & 72 & -154 & -201 & -170 & -90 & -104 & -84 \\
\hline $\mathbf{P}$ & 333 & 295 & 68.1 & 29 & -165 & -217 & -204 & - & -185 & -175 \\
\hline $\mathbf{Q}$ & 129 & 704 & 13.7 & 135 & -98 & -161 & - & - & - & - \\
\hline $\mathbf{R}$ & 45.2 & 351 & 44.7 & 62 & -56 & -183 & - & - & - & - \\
\hline $\mathrm{S}$ & $334^{*}$ & $444^{*}$ & 67.7 & 40 & $-116^{*}$ & $-210^{*}$ & - & - & - & - \\
\hline
\end{tabular}




\section{とがわかる。}

各鋼板の材料定数 $S_{0 i}, k_{i}, \sigma_{0 y}, k_{y}$ 扤よび標準試験片での nose temperature, $T_{N m}$ ，は第 2 表に示されている。

これらを(32) 武に代入して各鋼板の無限板の場合における亀裂長さ $c$ と脆性破壤発生温度 $\mathrm{T}_{\mathrm{i}}\left({ }^{\circ} \mathrm{C}\right)$ の関係を もとめると第 21 図に示すようになる（ただし, 安全率 $n=2.56$ )。第 18 図では軟鎆（鋼 A）の $T_{N}$ が一番低 温側に位置しているが，第 2 表に示すよ $5 に k_{i}$ と $k_{y}$ が大きいので $\mathrm{T}_{\mathrm{i}}-\mathrm{c}$ 曲線はかなり高温側へ移つている。

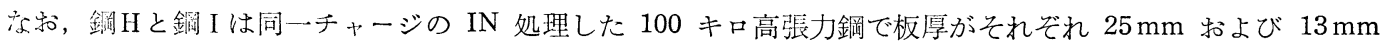
で，板厚效果の点からは鋼Hの方が高温側に位置する筈であるが，IN 処理鐝では厚板の方が靱性が良いという 治金的の面からの特别の琶由から，薄板の錩 I の方が高温側になつている。

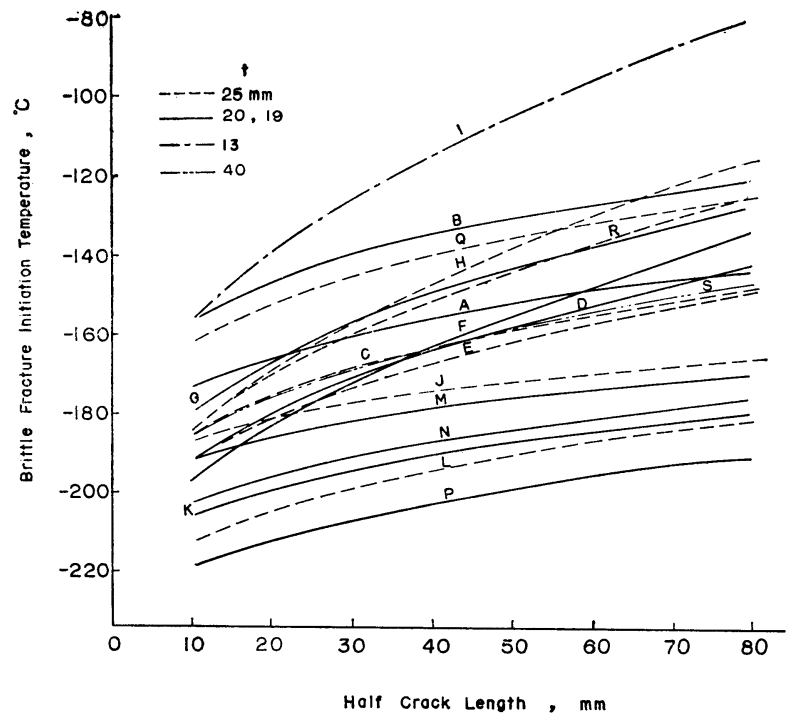

第 21 図 無限板の場合の亀裂長さと脆性破壞発生温度の関係

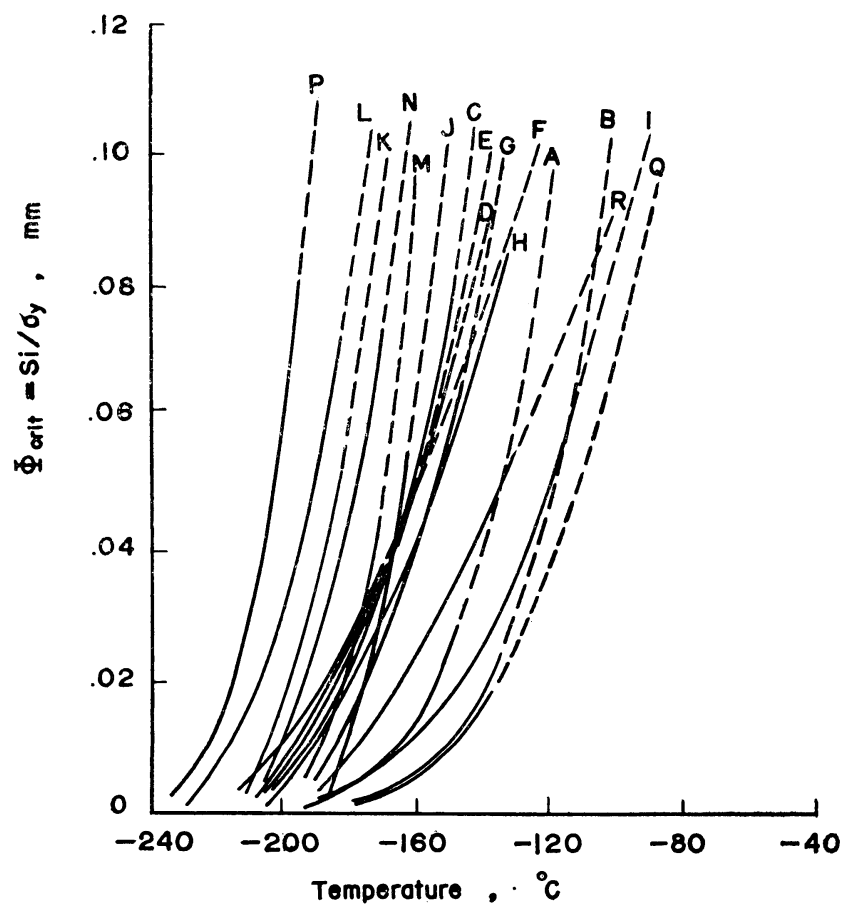

第 22 図切久先端部の塑性変位と温度の関係 
図より，亀裂長さの増加とともに脆性破壊発生温度は上昇し，高張力鋼は比較的高い温度で脆性破壊が発生す る可能性があり，低温用鋼はいずれも優秀で，調質アルミキルド鋼は $2.5,3.5 \% \mathrm{Ni}$ 鐸と同程度に良く，9\% $\mathrm{Ni}$ 鋼は最すすぐれていることがわかる。なお，鋼 PはNT 処理したものである。

Bilby らによる破壊発生時の亀裂先端部の塑性変位 $\Phi_{c r i t}$ は $S_{i}$ と $\sigma_{y}$ との間に（9）式の関倸があるので, 次式により各鋼ごとの温度との関係をもとめることができる。

$$
\begin{aligned}
\Phi_{c r i t} & =\frac{S_{i}}{\sigma_{y}} \\
& =\frac{S_{0 i}}{\sigma_{0 y}} e^{-\frac{k_{i}+2 k y}{T_{K}}}
\end{aligned}
$$

各供試鋼の材料定数 $S_{0 i}, \sigma_{0 y}, k_{i}, k_{y}$ が第 2 表に示されているので, (34) 式をもちいて各鋼板の場合の破壊

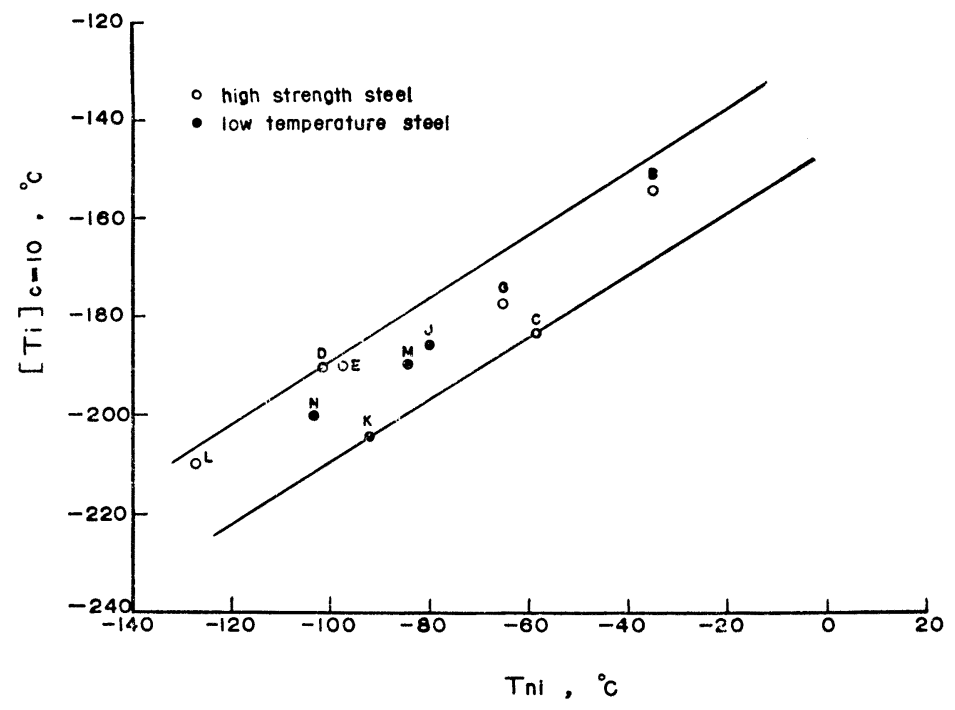

第 23 図 $c=10 \mathrm{~mm}$ の $T_{\imath}$ と $T_{n i}$ の関係

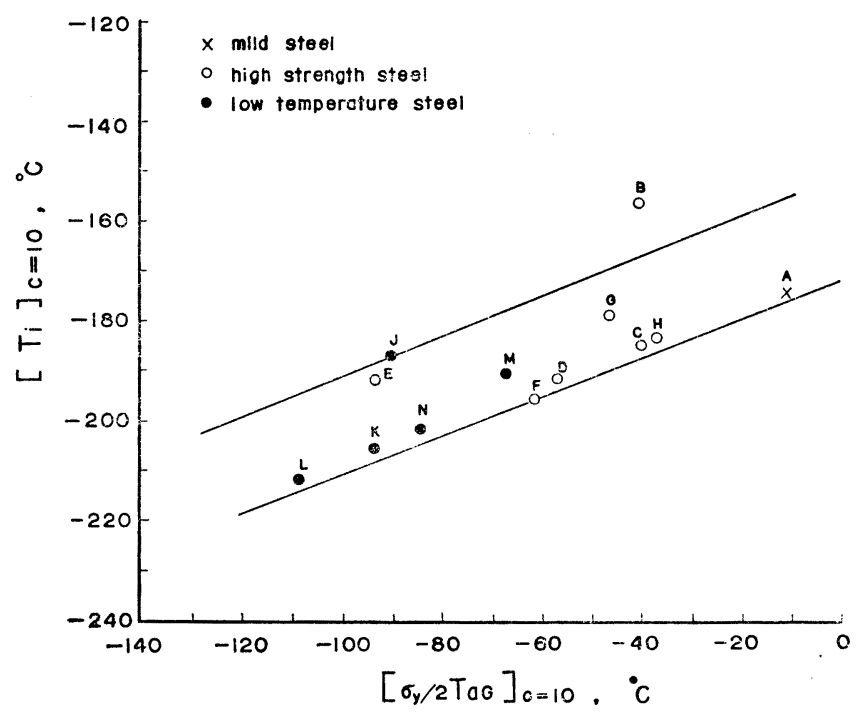

第 24 図 $c=10 \mathrm{~mm}$ の $T_{i}$ と $\sigma_{y / 2} T_{a G}$ の関倸
発生時に打壮る象裂先端部 の塑性变位 $\Phi_{c r i t}$ を種々の 温度にたいしてもとめるこ とができ, 第 22 四が得ら れる。

(6), (8), (9) 式は $\sigma<0.6 \sigma_{y}$ の場合のあので あるので (34) 式の関係す その応力の籁囲内で正しい ことになる。図中，破線は $\sigma \geqq 0.6 \sigma_{y} \quad$ に相当する分で あるので実線の部分のみに 注目すればよい。因より, 温度の上界とともに $\Phi_{c r t t}$ は增加すること, および低 温用䤲は低温です $\Phi_{c r t t}$ は かなり大きくてすぐれてい ることがわかる。切欠先端 の塑性変位は Moiré 法な ぞにより奏測して本試験結 果と比較検傠することがの ぞましく，両者の結果が一 致することがのぞましい。

4.3.6 各種脆性破壊試 験の遷移温度との相関性 : 各種銅板の脆性破壤発生温 度が亀裂長さの函数として 符 21 四のようにもとめら れたので，僬裂長さの $1 / 2$ ， c, が $10 \mathrm{~mm}$ の場合の破壞 発生温度 $\left[T_{i}\right]_{c=10}$ をを めると䇷 2 表に示す值が得 られる。これと各種脆性破 壦试踰の遷移温度のうらの 代表的なるのとの相関性を もとめ, 籍 23 図ないし 第 26 図に示吉。 


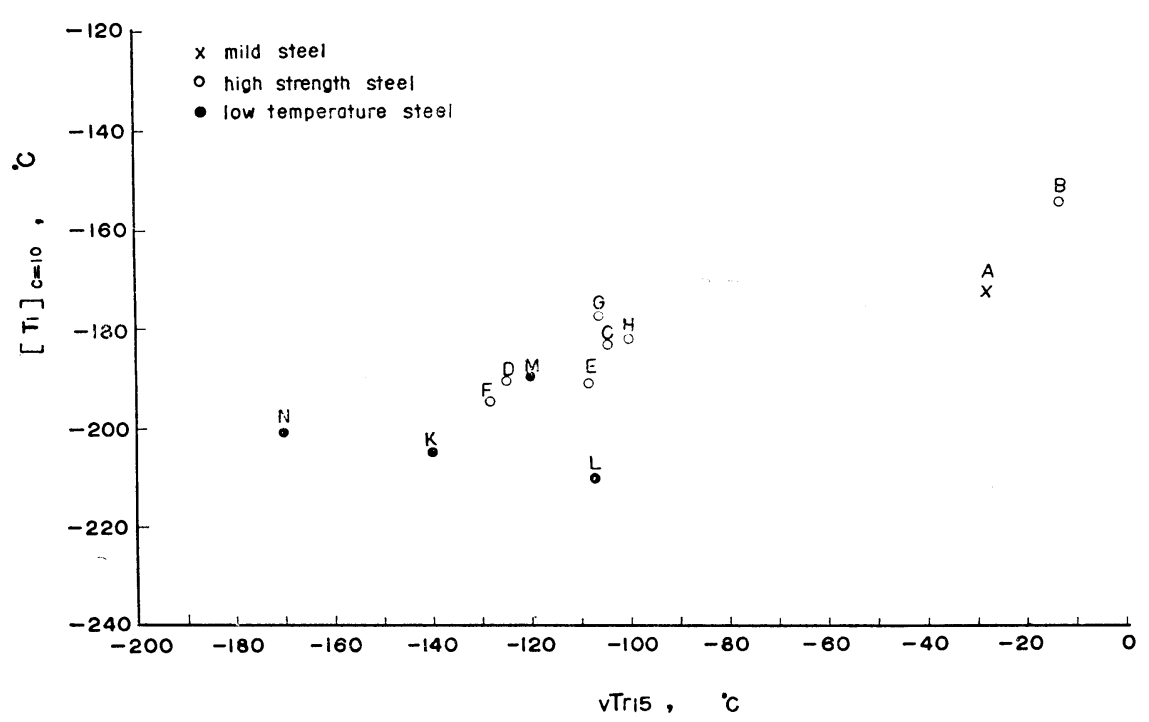

第 25 図 $c=10 \mathrm{~mm}$ の $T_{\imath}$ と ${ }_{V} T_{r 15}$ の関係

第 23 図は切欠部に衝撃力が加わる場合の発生特性を示すと考兄られている一様温度型 ESSO 試験の非発生 温度 $T_{n i}$ と $\left[T_{i}\right]_{c=10}$ との関倸を示し, 両者の間にかなり良い相関のあることがわかる。

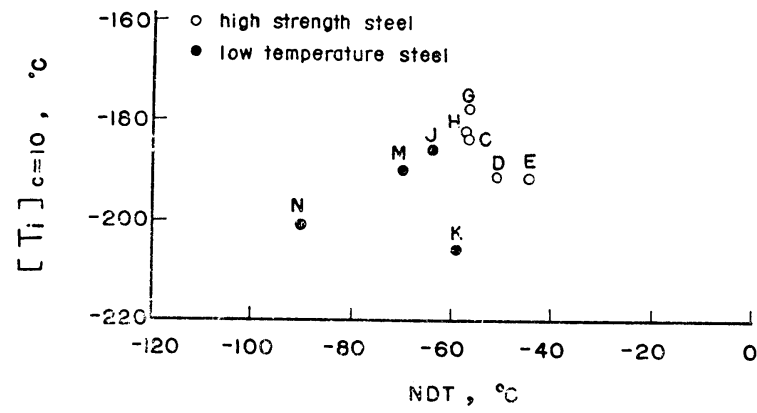

第 26 図 $c=10 \mathrm{~mm}$ の $T_{\imath}$ と NDT 温度の閵係

つぎに，第 24 四はごく短い亀裂長さ $(c=$ $10 \mathrm{~mm}$ ) で停止する場合の伝播停止特性を女， らわすと考えられている温度勾配型二重引張: 試験の停止温度 $\left[\sigma_{y} / T_{a G}\right]_{c=10}$ と $\left[T_{i}\right]_{c=10}$ と の関係を示す。図上り，両者の間に良い相関， のあることがわかる。

小型試験の代表的なるのとして広くもちい られているVノッチシャルピ衝撃試験の 15 $\mathrm{ft}-1 \mathrm{~b}$ 遷移温度 ${ }_{V} T_{r 15}$ と $\left[T_{i}\right]_{c=10}$ の関係を 第 25 図に示すが, 両者の間にいくらかの相 関性があるようである。

NRL 落重試験の NDT 温度と $\left[T_{i}\right]_{c=10}$

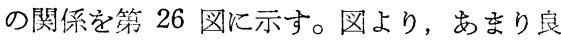
い相関関係がみられない。これより NDT 温度は発生特性をあらわするのではなくて，むしろ伝播停止特性をあ らわするのであることの裏付けの一つになるかもしれない。

\section{5 結論}

鋼板の脆㨫破壊発生特性をしらべる試駼法としての deep notch test について祫討を加えつぎの結墖が得ら れた。

（1）破㜃発生時の塑性表面エネルギーと亀裂先端の塑性変位や開口変位との関倸があきらかになつて物理的 意味が示された。

（2）有限巾の deep notch test 試験片で得られた general yielding 限界曲線の突端,すなわち nose temperature, $T_{N}$, がわかると無限板の場合に各温度での降伏点を基準にした任意の安全率の場合の亀裂曼 さと脆性破壊発生温度の関係をもとめることができる。

（3）軟銅では低応力脆性破壊の領域（領域 (1)）々延性破壞の領域（領域 (iii)）の中間飞約 $100^{\circ} \mathrm{C}$ の温度領域 （領域 II）があり，ここでは general yielding 後に脆性破壊するが，60 キロ高張力鋼ではこの領域が 
ほとんど存在しない。

（4）Griffith-Orowanのエネルギー条件式により脆性破壊発生時の応力-温度曲線をるとめることは general yielding 直前のかなり高い応力レベルまで，およびかなり短い切欠まで適用できる（領域 (1) 内に拉 $\tau) 。$

（5）先端半径が $0.1 \mathrm{~mm}$ の機械的切欠は脆性破壤発生の分野では自然智と同等にとり女つかつてよい。

（6）切欠先端部の塑性域の大きさは温度の上界とともに增加する。

（7）同一龟裂長さにたいして帊厚の増加とともに脆性破壊発生温度は上畀し，その上悡率は $0.9^{\circ} \mathrm{C} / \mathrm{mm}(た$ だし $c=10 \mathrm{~mm}$ の場合）で，板厚が約 $30 \mathrm{~mm}$ 以上では汪とんど変化しなくなる。また同一温度では放 厚が大さくなるほど脆性破壊が発生する奄裂長さは小さくなる。

（8）各種鋼板の脆性破壞発生温度と亀裂長さの関係をもとめ材質を評価した。

（9） deep notch test による鋼板の脆性破壞発生特性は，一樣温度型 ESSO 試験の $T_{n i}$ 扎よび温度勾配型 二重引張試験による停止亀裂長さが $10 \mathrm{~mm}$ の停止温度との閐に良い相関があるが， NRL 落重試験の NDT 温度との間に相関性は認められない。

今後の研究課題としては，鋼板の母材としての脆性破壞発生特性が deep notch test によりもとめられたの で，溶着鋼，溶接ボンド部，熱影響部の特性をしらべたり，曲率のある板（円筒容器やパイプの場合）と平板の 関連性，塑性歪や繰返し荷重が脆性破壊発生特性におよぼす影響等をしらべる必要がある。

謝辞

本研究を括こな5にあたり終始かわらぬ激励をたまわつた石川島播磨重工業 K.K. 技術研究所副所長秋田博 土ならびに種々貴重な討論をたまわつた造船協会電気溶接委員会第 6 分科会主査金沢教授をはじめ各委員に厚 くお礼申しあげます。

また，実験の遂行ならびに解析等に大いに努力して下さつた船舶技術研究所 船体構造部材料研究室の前中， 北村，高橋各研究員をはじめ村上，坂本，鈴木の諸君に深甚の謝意を表します。

最後に，鋼板を提供して下さつた製鉄各社に叔を申しあげます。

参考文 献

1）秋田好雄，池田一夫，岩井宣雄：脆性破壞発生飞関する研究（第 1 報)-Deep Notch Test について, 造 船協会論文集，第 116 号（昭和 39 年）, p. 136

2) 木原博, 池田一夫：各種高張力鋼执よび低温構造用鋼の脆性破壞発生特性，溶接学会昭和 40 年度春季講 演会にて発表（印刷中）

3）寺沢一雄，大谷碧，吉田俊夫，寺井清：高温予歪が鋼の破壞応力曲線におよ持す影響の研究，造船協会 論文集, 第 110 号（昭和 36 年), p. 183

4) A. A. Griffith : The Phenomena of Rupture and Flow in Solid, Phil. Trans. Roy. Soc., 221, (1920) p. 163

5) E. Orowan : Fundamentals of Brittle Behavior in Metals, Fatigue and Fracture of Metals, MIT, (1950), p. 139

6) A. A. Wells : Application of Fracture Mechanics at and beyond General Yielding, BWRA Report, British Welding Journal, (1963)

7) B. A. Bilby, A.H. Cottrell and K.H.Swinden : The Spread of Plastic Yield from a Notch, Proc. Roy. Soc., A 272, (1963), p. 304

8）日本溶接協会 鉄鋼研究委員会：溶接構造物の脆性破罜防止のための鋼材の材質判定基萆の確立に関する 研究, (1962) 